\title{
The Surgical Treatment of Plagiocephaly
}

\author{
Plajiosefalinin Cerrahi Tedavisi
}

\author{
Gokalp SILAV ${ }^{1}$, Gulden $\mathrm{AVCI}^{2}$, Mithat $\mathrm{AKAN}^{3}$, Gaye TAYLAN ${ }^{4}$, Ilhan ELMACI ${ }^{1}$, Tayfun AKOZ ${ }^{4}$ \\ ${ }_{1}^{1}$ Acibadem University, Faculty of Medicine, Department of Neurosurgery, Istanbul, Turkey \\ ${ }^{2}$ Canakkale Onsekiz Mart University, Faculty of Medicine, Department of Plastic, Reconstructive and Aesthetic Surgery, Canakkale, Turkey \\ ${ }^{3}$ M. H. Istanbul Okmeydani Education and Research Hospital, Department of Plastic, Reconstructive and Aesthetic Surgery, Istanbul, Turkey \\ ${ }^{4}$ M. H. Kartal Dr. Lutfi Kirdar Education and Research Hospital, Department of Plastic, Reconstructive and Aesthetic Surgery, Istanbul, Turkey
}

Correspondence address: Gulden AVCI / E-mail: drguldenavci@hotmail.com

\begin{abstract}
AIM: Anterior plagiocephaly usually occurs with premature synostosis of the ipsilateral half of the coronal suture. The forehead is flattened on the affected side, with a backward and upward displacement of the affected orbit. The bulging of the calvaria may occur in the contralateral parietal area.

MATERIAL and METHODS: This article presents the surgical techniques used over 7 years to treat plagiocephalic children. Eleven patients with unilateral coronal synostosis treated during 2003-2010 were analyzed retrospectively. The study included reviews of pre and postoperative computed tomography scans, operative techniques, clinical outcomes and complications. Unilateral orbital advancement with "tongue in groove" was performed in 5, and bilateral orbital advancement in 6 cases. Pre and postoperative anthropometric measurements were used to document the amount of advancement of the elevated and recessed orbita, and the amount of withdrawal of the contralateral side.

RESULTS: The mean age of the patients at time of surgery was 11 months. The preoperative values of the orbital height and retrusion were $0.68 \mathrm{~cm}$ and $1.87 \mathrm{~cm}$, respectively. They were recorded as $-0.1 \mathrm{~cm}$ and $0,63 \mathrm{~cm}$, postoperatively. Mean follow-up was 36 months, neither neurological sequelae nor other significant complications were encountered.
\end{abstract}

CONCLUSION: The surgical corrections have resulted in significant improvements in skull shape and high patient/parent satisfaction.

KEYWORDS: Plagiocephaly, Unilateral, Coronal synostosis, Fronto-orbital advancement

ÖZ

AMAÇ: Anterior plajiosefali genellikle koronal sutürun ipsilateral yarısının erken sinostosisi sonucu oluşur. Etkilenen yöndeki alın bölgesinde düzleşme olurken aynı taraftaki orbita geriye ve yukarıya doğru yer değiştirir. Karşı taraftaki parietal bölgede kabarıklık olabilir.

YÖNTEM ve GEREÇ: Bu çalışmada, plajiosefalik çocukların tedavisinde 7 yıldır tarafımızdan yapılan cerrahi teknikler ve sonuçları sunulmaktadır. Retrospektif olarak 2003-2010 yılları arasında tek taraflı koronal synostosisi olan 11 hastaya uygulanan cerrahi tedaviler ve sonuçları incelendi. Bu çalışmada ameliyat öncesi ve sonrası bilgisayarlı tomografileri, ameliyat teknikleri, klinik sonuçları ve komplikasyonları analiz edildi. Beş hastaya unilateral orbital ilerletme, 6 vakaya ise bilateral orbital ilerletme yapıldı. Ameliyat öncesi ve sonrası antropometrik ölçümler yapılarak geride ve yukarıda olan orbitanın ilerletilme miktarı, kontralateral tarafın ise geriye alınma miktarları yani plajiosefalinin düzelme miktarları dokümante edildi.

BULGULAR: Ameliyat sırasında hastaların yaş ortalaması 11 aydı. Ameliyat öncesi orbita yüksekliği ve retrüzyon miktarı sırasıyla ortalama $0.68 \mathrm{~cm}$ ve $1.87 \mathrm{~cm}$ idi, ameliyat sonrası bu değerler ise sırasıyla $-0.1 \mathrm{~cm}$ ve $0.63 \mathrm{~cm}$ bulundu. Hastaların ortalama takip süresi 36 ay olup herhangi bir komplikasyon görülmedi.

SONUÇ: Cerrahi tedavi sonrası kafatasında belirgin düzelme olurken hasta ve ebeveyin memnuniyeti de yüksek olmuştur.

ANAHTAR SÖZCÜKLER: Plajiosefali, Unilateral, Koronal sinostosis, Fronto-orbital ilerletme

\section{INTRODUCTION}

The term plagiocephaly is used to describe the unilateral flattening of an anterior or posterior quarter of the skull. Plagiocephaly may be either deformational or organic. The organic plagiocephalies are caused by premature synostosis of the coronal suture or lambdoid suture. In nearly every case, anterior plagiocephaly has been described in association with unilateral coronal synostosis $(5,8,22)$, but it is well known also to occur in association with synostosis of other parts of the coronal ring such as the frontosphenoidal or frontoethmoidal sutures $(32,44)$. In some rare cases it has been reported to be the result of fusion of the frontosphenoidal suture or the frontozygomatic suture alone (40). Unilateral coronal synostosis accounts for $20-30 \%$ of synostoses in infancy (4).

In this report we aim to analyze the results of an operative series of 11 patients with anterior synostotic plagiocephaly. 


\section{MATERIAL and METHODS}

Eleven patients with anterior plagiocephalies were operated by a team of Plastic and Reconstructive Surgeons and Neurosurgeons between 2003 and 2010. The results were analyzed retrospectively. The following determinants were documented; ages, genders of the patients, accompanying medical conditions, the involved sutures, surgical interventions performed, hospitalization periods, complications, followup periods, preoperative and postoperative computed tomography scans.

\section{Operative Procedure}

The head and face of the patient were surgically cleaned and draped on supine position, leaving the midface and periorbital regions uncovered. The scalp was injected with $0.25 \%$ lidocaine solution with 1:200000 epinephrine. Approximately $30 \mathrm{ml}$ of this solution was used. Infiltration of the solution 15 to 30 minutes before incision has improved surgery by means of vasoconstriction. A bicoronal incision was made and Raney clips were placed on both sides of the wound to maintain meticulous hemostasis. Scalp was dissected to the temporal and supraorbital region through subgaleal plane. At the upper border of the temporalis muscle the incision was made through the periosteum and the muscle was left attached to the scalp. Deep to the temporalis muscle, the temporalis fossa was exposed. Transmission to subperiosteal dissection plane was performed 1 to $2 \mathrm{~cm}$ above the superior orbital rim. An anteriorly based periosteal flap was created, thus exposing the supraorbital rims, the base of the nasal bone, and the superior part of the lateral orbital walls. Supraorbital nerves were released from supraorbital rim (Figure 1A, B). The orbital roof was dissected subperiosteally. The dissection of the lateral orbit margin continued inferiorly below the frontozygomatic suture. Craniotomy was performed posterior to the fused coronal suture bilaterally. The frontal bone was removed, split, reshaped, and placed in for the optimal orientation and cosmetic result (Figure 2A-C). The entire supraorbital bar was excised (Figure $3 \mathrm{~A}$ ). In a unilateral correction the bones were cut to the level of the medial orbital margin of the opposite orbit. Supraorbital bar was remodeled by advancing the synostotic side (Figure 3B, C). The orbital bar was removed after the frontal bone was excised in all cases.

In 6 cases with severe deformities, bilateral fronto-orbital advancement was performed. The similar bone cuts were made bilaterally. Supraorbital bar was remodeled either by a interpositional-bone graft placed in the middle of the bar and/or absorbable plaque-screw. Further remodeling was established by advancing the synostotic side together with posterior positioning of the contralateral side. The forehead is split in the midline and the resulting bone pieces are adjusted and replaced in the most optimal position (Figure 4A-D).

The supraorbital bar and frontal bones were fixated with absorbable plates, wires or sutures. The temporal muscle was also advanced back and fixed to its original location. Scalp closure was made following saline irrigation of the wound.
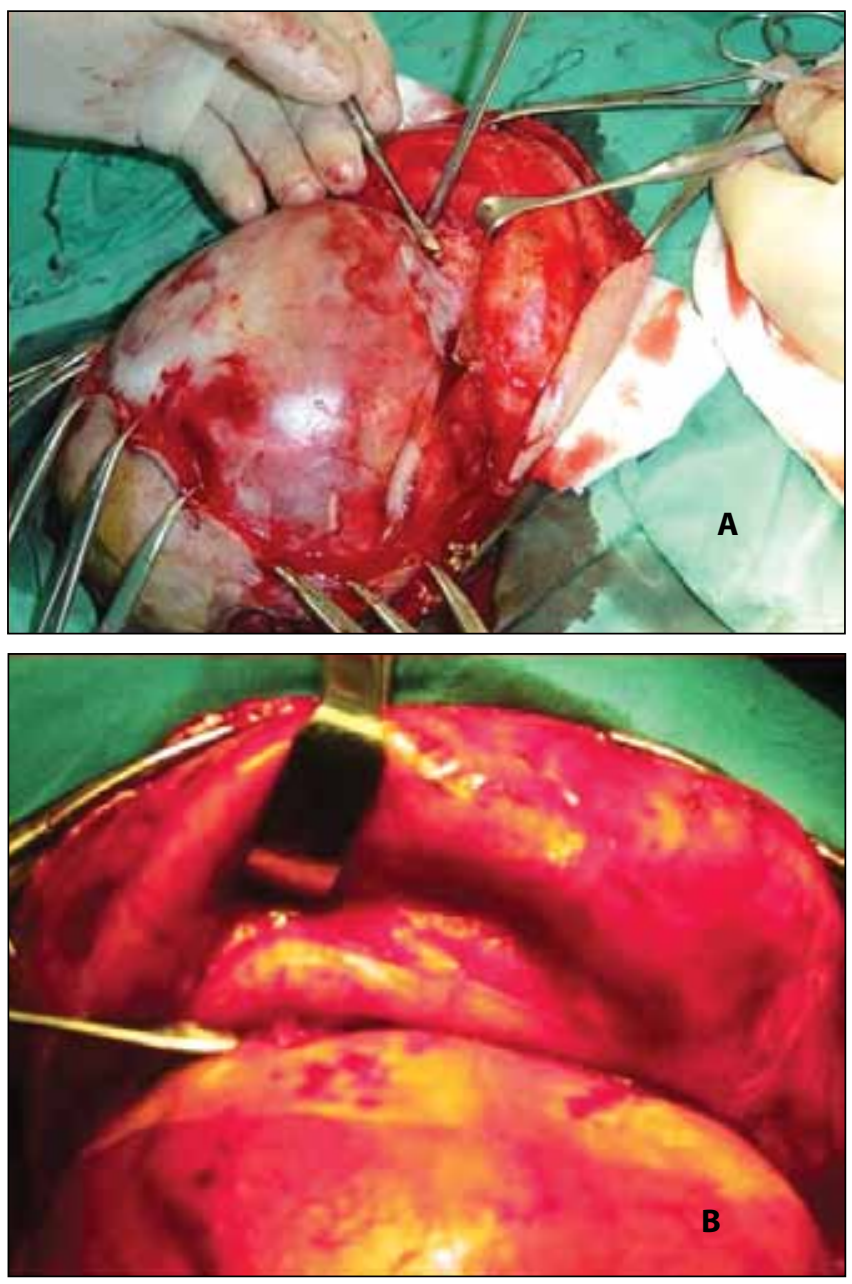

Figure 1:A) Dissection of scalp at subgaleal plane and appearance of subperiosteal dissection at approximately $2 \mathrm{~cm}$ superior part of supraorbital region. B) Exploration and preservation of supraorbital nerves.

\section{RESULTS}

Our neurosurgery department and plastic surgery department have an operative series of 11 patients with unilateral coronal craniosynostosis between 2003 and 2010. There were 6 girls and 5 boys affected by unilateral anterior plagiocephaly. Primary procedures were performed at an average age of 11 months, with an average postoperative follow-up of 36 months. Personal and familial histories of the patients were nonspecific.

A preoperative clinical examination was performed in all patients and physical findings were documented by photographs. The common features of all patients were the presence of unilateral flattening of the involved forehead with the orbit elevated and recessed on the affected side. The supraorbital margins were also recessed in all patients. Moreover, some degree of facial asymmetry (due to retraction of the malar bone) was evident in all children. Preoperative, 

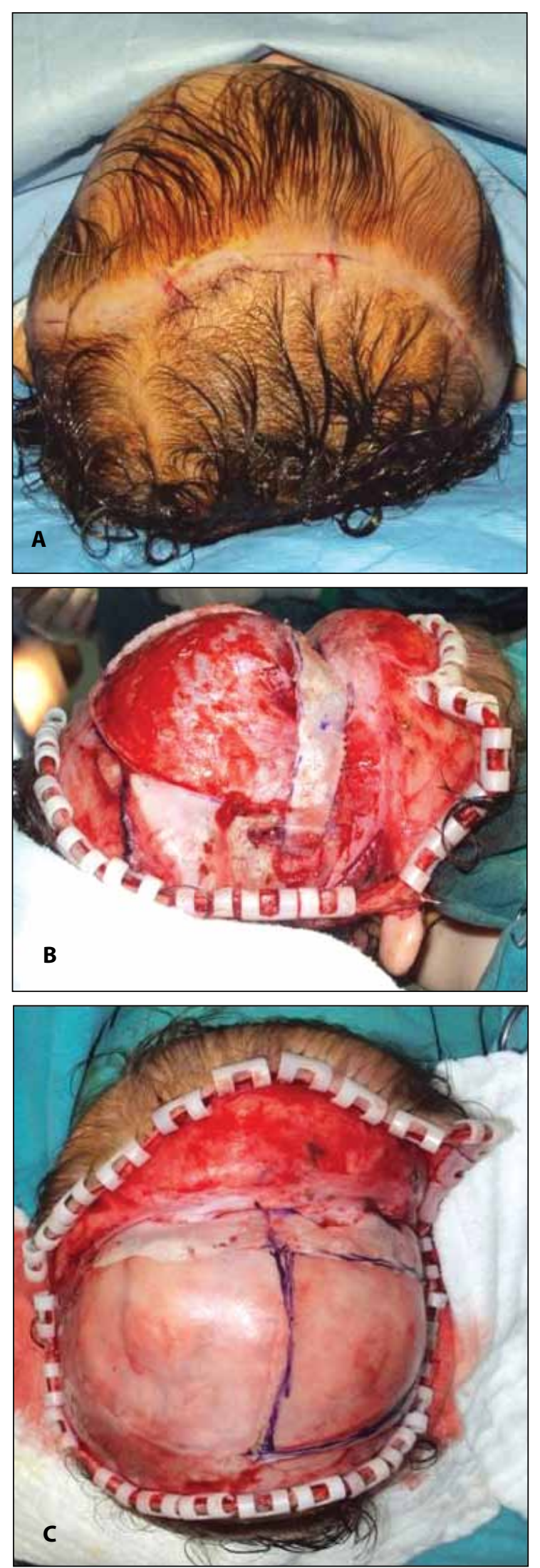

Figure 2A-C: Appearances of frontal bone segment removed, remodeled supraorbital bar after fixation. three-dimensional computed tomography (3D CT) scans and immediate postoperative computed tomography scans (CT) had been conducted in all patients.

The average duration of surgery was 3 hours and 15 minutes and ranged from 1.5 to 7 hours. Blood loss ranged between $65 \mathrm{cc}$ and $240 \mathrm{cc}$ (mean 130cc). The average hospital length of
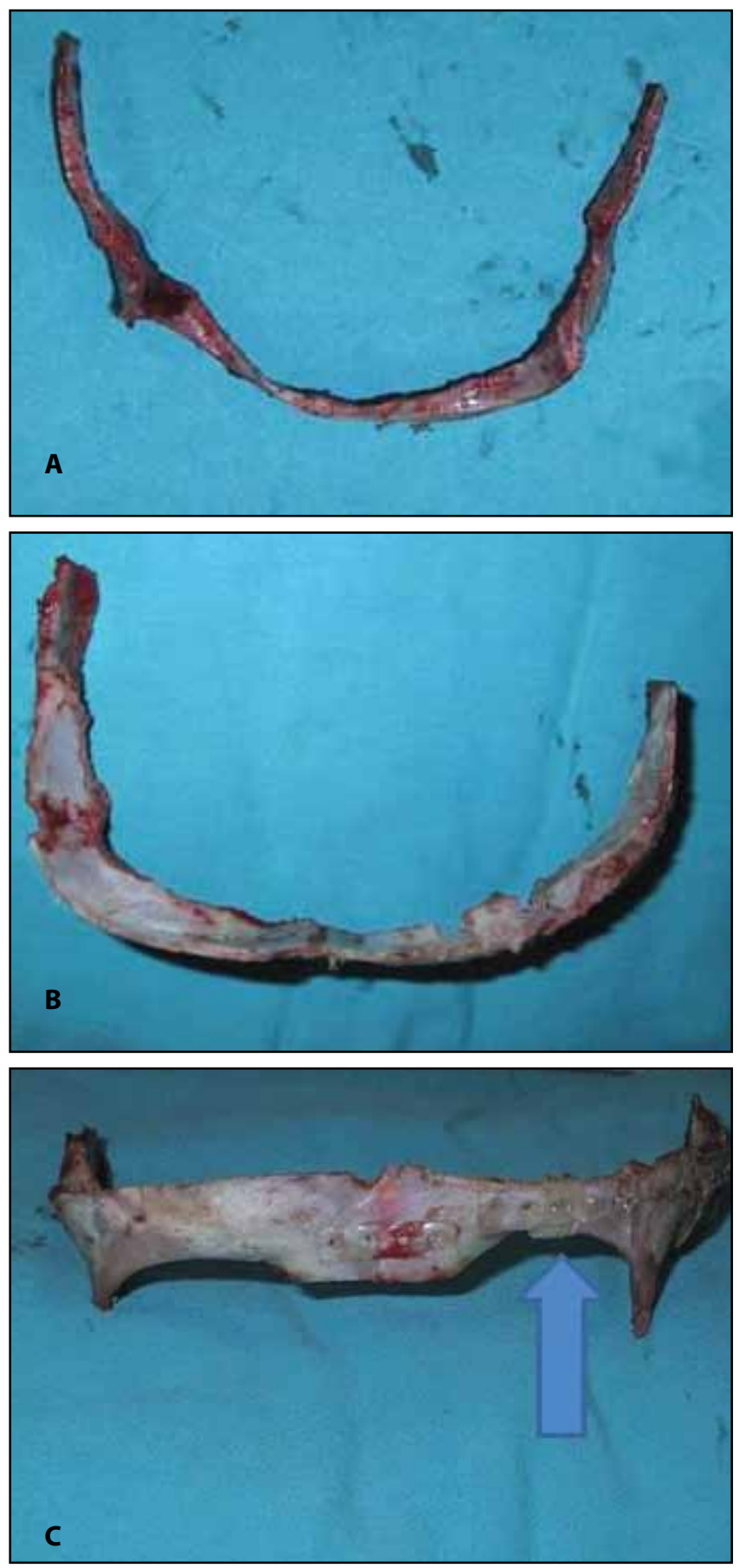

Figure 3: A) Appearance of supraorbital bars removed after osteotomies. B-C): Supraorbital bar, remodeling by a midline interpositional-bone graft and/or absorbable plaque-screw. 

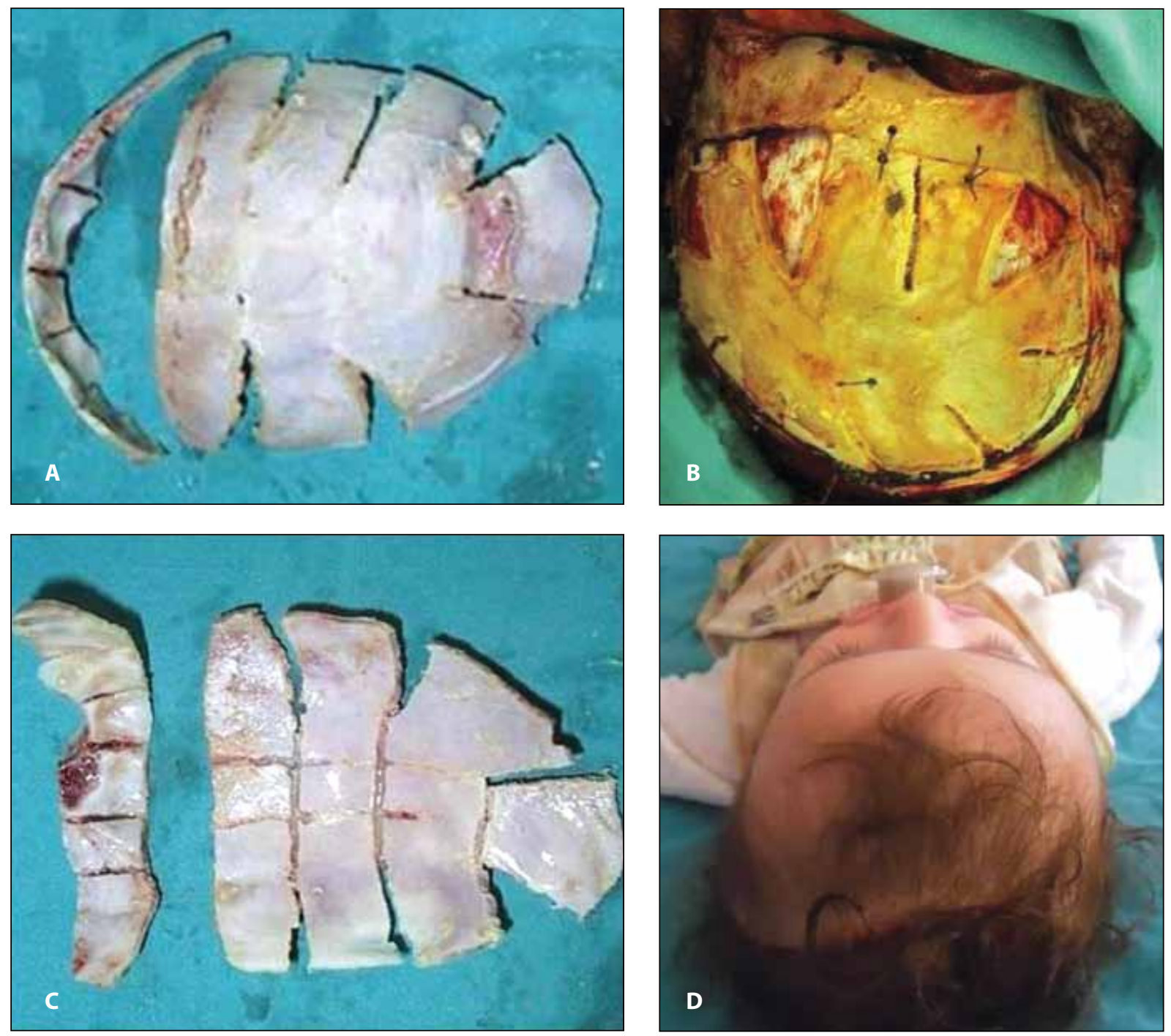

Figure 4A-D: Appearances of bilateral fronto-orbital advancement with remodeled of frontal bone.
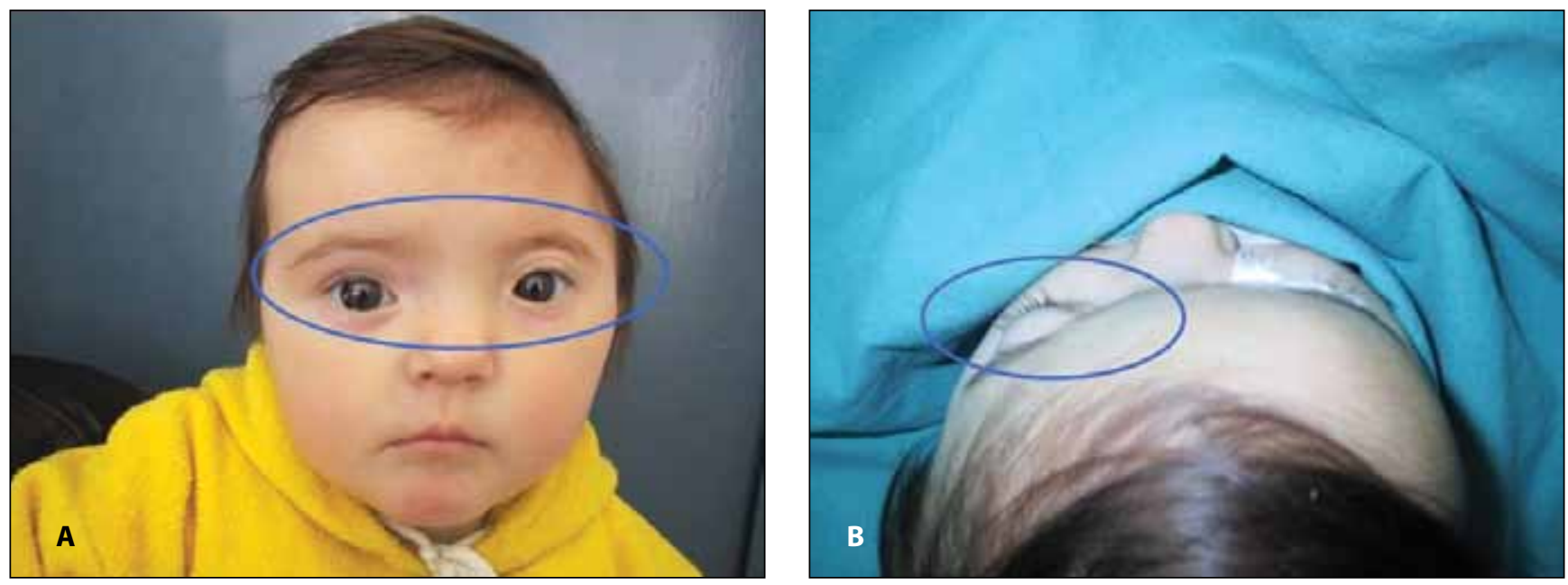

Figure 5: A) Appearances of intercanthal and biocular distances, B) Preoperative and postoperative anthropometric measurements were used to document the correction of plagiocephaly, correction of elevated and recessed orbita. 
stay was 7.3 days (all patients were kept in the hospital for a minimum of 4 days.) The postoperative clinical course was uneventful in all cases. Mean follow-up of the patients was 36 months ( 6 months and 5 years) and no revisions were required during this period.

The physical examinations and quantitative measurements to analyze plagiocephaly severity were performed. Preoperative and postoperative anthropometric measurements were used to document the correction of plagiocephaly, correction of elevated (Figure 5A) and recessed orbita (Figure 5B), as previously described (22). The amount of recession of the orbita was measured from the corneal apex to the supraorbital rim. The amount of elevation of the orbita was measured in relation to the other side (Table I). The preoperative mean height and the retrusion of the orbita were $0.68 \mathrm{~cm}$ and $1.87 \mathrm{~cm}$, respectively. Their postoperative values were determined as $-0.1 \mathrm{~cm}$ and $0,63 \mathrm{~cm}$. The patients were evaluated according to Sloan classification of surgical results regarding cosmetic improvement (Table II) and photographic documentations were prepared during follow-ups of three months. According to the Sloan classification, 5 patients were assessed to be Sloan 1 (Figure 6A, B), 3 patients were assessed to be Sloan 2 (Figure 7A-C, 8A-D), 2 patients to be Sloan 3 and
1 patient to be Sloan 4 (Figure 9A-D, 10A-D). One patient was evaluated as Sloan 4, and revision surgery was planned.

\section{DISCUSSION}

Plagiocephaly is a descriptive term derived from the Greek "plagio" (oblique or slant) and "kephale" (head). The causes of anterior plagiocephaly are heterogeneous (21). Anterior plagiocephaly results when abnormal forces act on the growing craniofacial skeleton. These forces are either external (deformational) or the result of a malformation (synostosis). The deformational forms of anterior plagiocephaly are by the most common, with reported incidence of 1 in 300 live births. The anterior plagiocephaly seen in this circumstance may be an intrauterine phenomenon or it may occur postnatally, resulting from the persistent infant head tilt and repetitive sleep positioning $(27,41)$.

Anterior plagiocephaly may also be a manifestation of abnormal development of the coronal suture. Coronal synostosis may be either unilateral or bilateral. In a 21 year experience consisting of 116 patients with coronal synostosis, $47 \%$ were unicoronal, $9 \%$ bicoronal without associated syndromes, 34\% were bicoronal associated with a syndrome, and the remaining $20 \%$ were associated with multiple
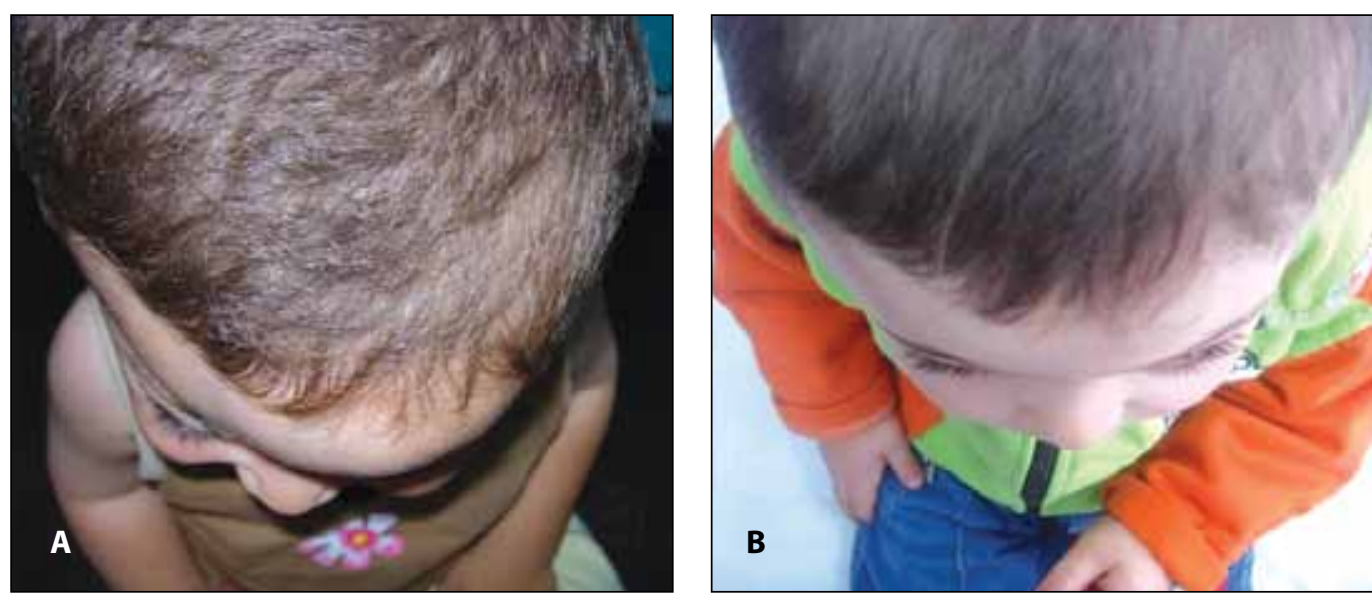

Figure 6:

A) Preoperative appearances of 2 years plagiocephaly patient

B) Postoperative appearances of the patient after 3 years, Sloan Class 1.
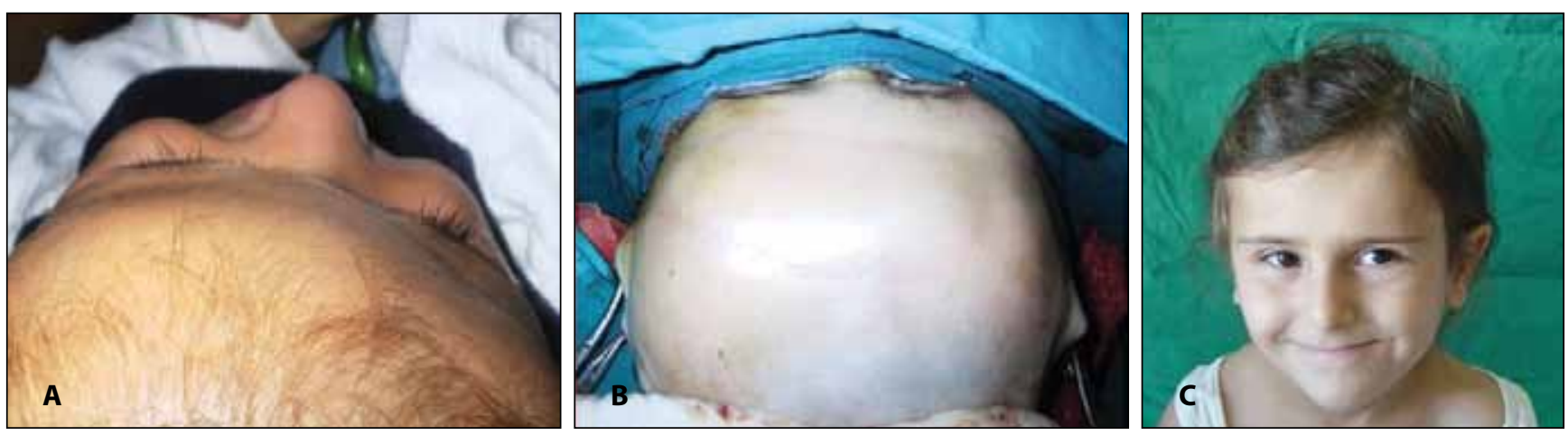

Figure 7: A) Preoperative appearances of 14 months plagiocephaly patient, B-C) Postoperative appearances of the patient just after operation, after 3 years, Sloan Class 2 . 

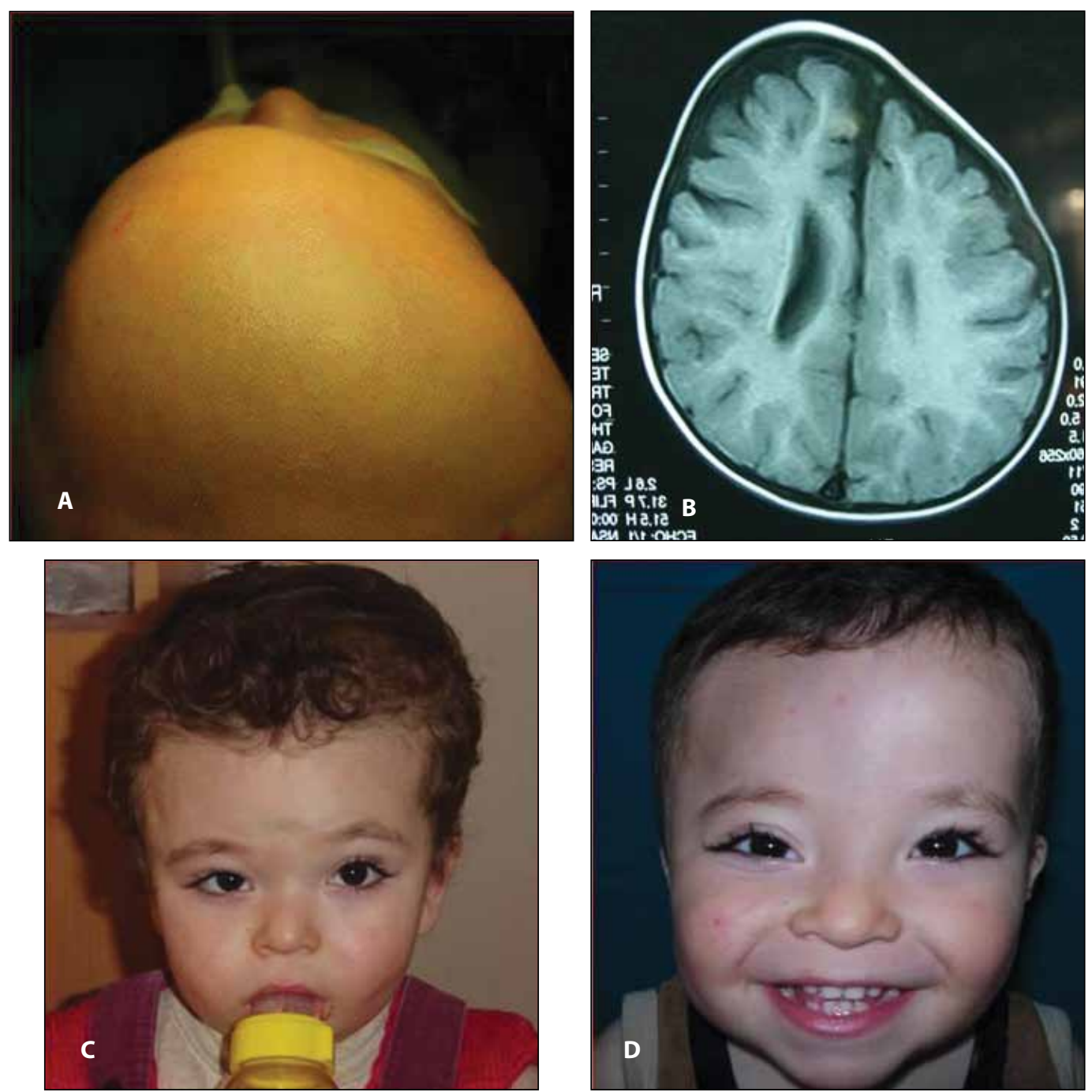

Figure 8: A-B) Preoperative appearances of 11 months plagiocephaly patient. CT scan imagining, C-D) Postoperative appearances of the patient, Sloan Class 2.

Table I: The Results of the Postoperative Anthropometric Measurements

\begin{tabular}{|c|c|c|c|c|c|}
\hline \multirow{2}{*}{ Patients } & \multicolumn{3}{|c|}{ Elevation } & \multicolumn{2}{c|}{ Korap-Supor (Retrusion) } \\
\cline { 2 - 5 } & Preop. & Postop & Preop. & Postop \\
\hline 2 & 1,1 & $-0,2$ & 2,2 & 0.5 & 1,2 \\
\hline 3 & 0,7 & 0.5 & 1,9 & 0.4 & Sloan 1 \\
\hline 4 & -0.5 & -1.1 & 1,5 & 0,8 & Sloan 2 \\
\hline 5 & 1,2 & 0.3 & 2,2 & 0,5 & Sloan 2 \\
\hline 6 & 0.7 & -0.4 & 1,4 & 0.7 & Sloan 4 \\
\hline 8 & $-0,2$ & 0,4 & 1,7 & 0.6 & Sloan 3 \\
\hline 1 & 0,8 & $-0,1$ & 2,1 & 0.5 & Sloan 3 \\
\hline 11 & 0.9 & -0.1 & 1.8 & 0.4 & Sloan 1 \\
\hline Mean & 1.1 & 0.2 & 1.7 & 0.8 & Sloan 2 \\
\hline
\end{tabular}


Table II: Sloan Classification: In Attempting to Evaluate the Surgical Results, We Used the Sloan Classification

\begin{tabular}{l|l} 
Class 1 & good-excellent result, no visual irregularity and no irregularity felt by palpation
\end{tabular}

Class 2 Good-excellent result, no visual irregularity, irregularity felt by palpation is present but reoperation is not required (e.g., palpable but invisible wire, plaque-screw or bony prominences)

Class 3 Good-excellent result together with visual irregularities, but reoperation is not required (e.g., visible plaquescrew, wire, bony prominences or bone defects not affecting surgical correction)

Class 4

Good-excellent result together with visual or palpable irregularities requiring surgical correction (e.g., removal of plaque-screw)

Class $5 \quad$ Presence of problem affecting surgical correction but not requiring reoperation (e.g., presence of mild asymmetry of forehead)

\begin{tabular}{l|l} 
Class 6 & Asymmetry disturbing correction in general and severe sufficient enough to require reoperation
\end{tabular}

Class $7 \quad$ Presence of problems affecting surgical outcome and reoperation offered by the surgeon but unwillingness of the family against reoperation
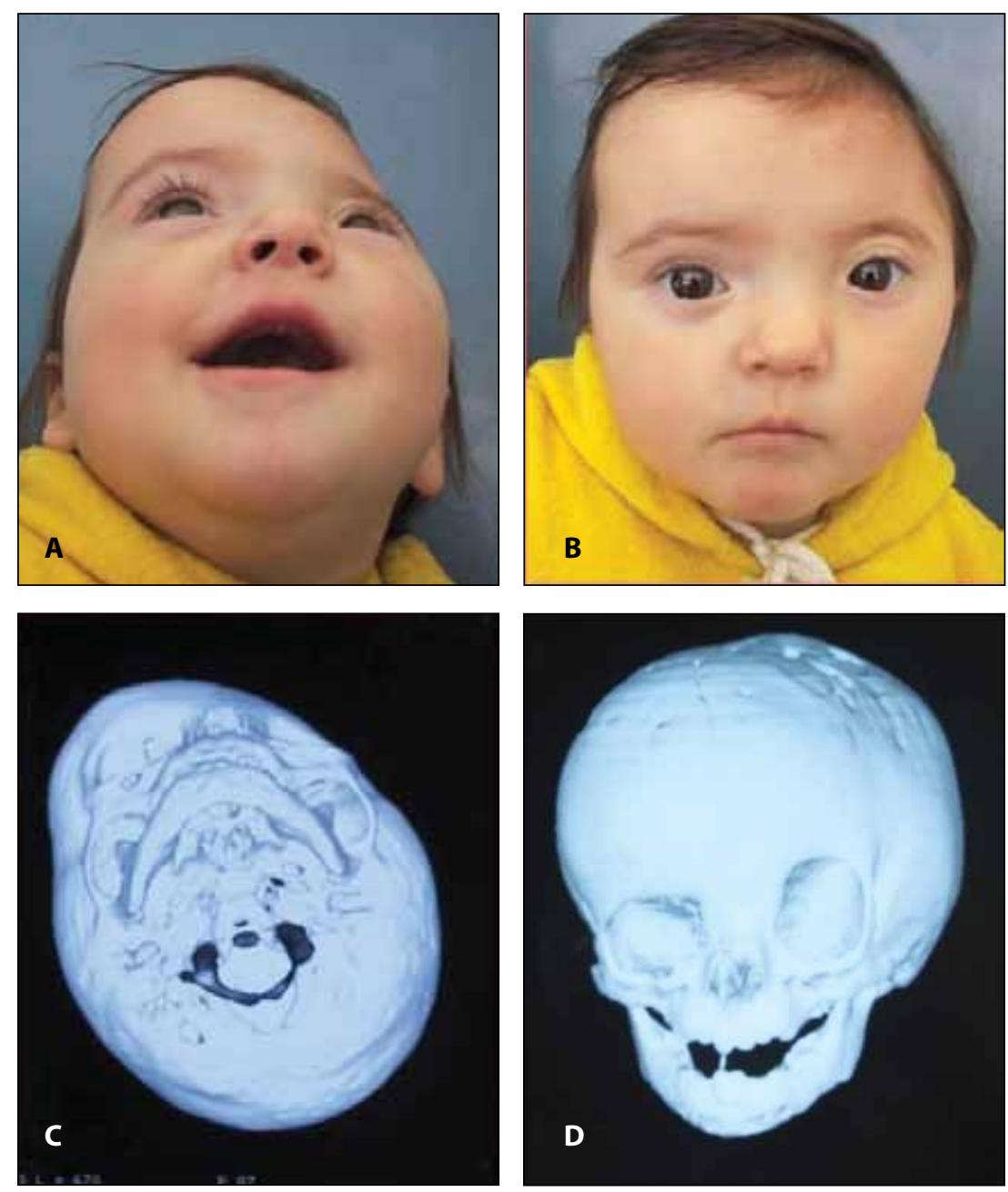

Figure 9: A-B) Preoperative appearances of 10 months plagiocephaly patient, C-D) Preoperative appearances of 3D CT imagining. 

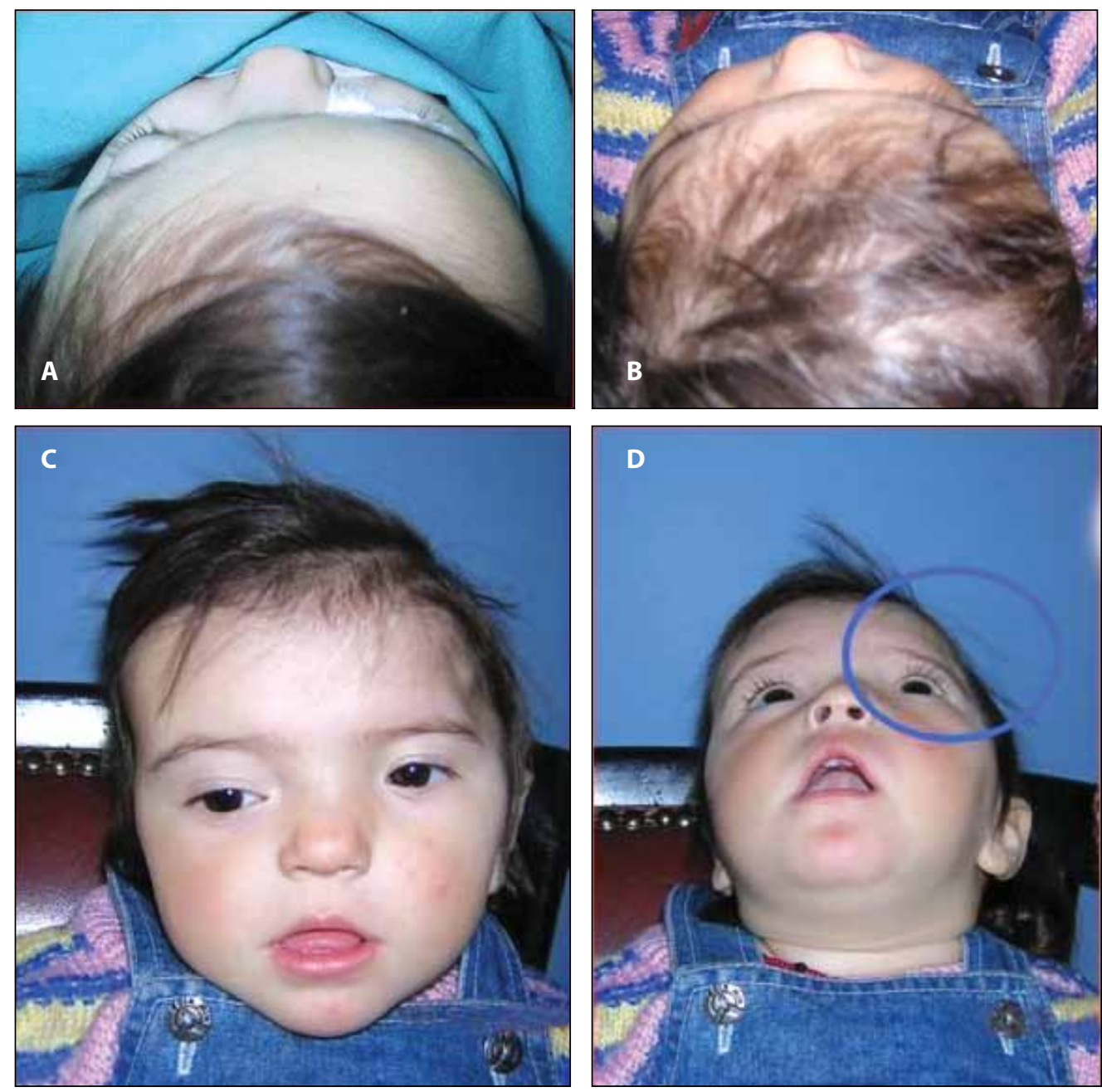

Figure 10: A) Preoperative appearances of 10 months plagiocephaly patient, B-D) Postoperative appearances of the patient, Sloan Class 4.

suture synostosis (35). Anterior plagiocephaly resulting from unilateral coronal synostosisis (UCS) is a relatively uncommon disorder and occurs in 1 of 10000 live births (3). It is the third most common type of craniosynostosis $(1,10,20)$. Unilateral coronal synostosis accounts for $20-30 \%$ of synostoses in infancy. Most cases of unilateral coronal synostosis are sporadic and non syndromic. There are, however, examples of familial UCS, such as Seatre-Chotzen syndrome (7). Unilateral coronal craniosynostosis is the most common hereditary form of single-suture fusion. First described in 1994, several families with hereditary 'non-syndromic craniosynostosis' have been reported with variable occurrence of unilateral or bilateral coronal synostosis (19). In 1997, a mutation in fibroblast growth factor receptor 3 (FGFR3P250R) was described in patients with apparently isolated coronal craniosynostosis and is now known as Muenke syndrome (37). This FGFR3P250R mutation has since been identified in approximately $10 \%$ of isolated unilateral coronal synostosis and a greater percentage of bilateral cases $(37,43,46)$.
Cunningham and Heike have identified cases of isolated sagittal and coronal synostosis with novel mutations of the transcription factor TWIST1 that causes the syndromic form of craniosynostosis known as Saethre-Chotzen syndrome (11). This research suggests that mutations in genes that cause syndromic forms of craniosynostosis (Muenke, AntleyBixler and Saethre-Chotzen syndrome) are also associated with isolated single-suture fusion without other syndromic features. Thus, they recommend that all children with isolated unilateral or bilateral coronal synostosis are offered molecular testing for causative mutations in FGFR3 and TWIST1 (11).

The dominance of females over males is $68 \%$ (16). Plain radiography permits us to distinguish the malformational plagiocephaly secondary to premature synostosis of a cranial suture (6) and deformational plagiocephaly without synostosis, due to positional or functional (2) mechanisms in simple cases, but three-dimensional (3D) CT scanning is the key to the diagnosis and study of the deformation $(31,34,36)$. 
Unicoronal synostosis causes regional growth restriction and compensatory expansion of the neighboring tissues, producing overt frontoorbital dysmorphology. Infants with synostotic frontal plagiocephaly (unilateral coronal synostosis) have a characteristically asymmetric face and anterior cranium. Characteristic deformities ipsilateral to the synostosis include flattening of the frontal bone and ipsilateral forehead, ipsilateral elevation-recession of the supraorbital rim, narrowing and lateral deviation of the orbit. The nasal root is deviated toward the affected side, whereas the cartilaginous framework is rotated slightly to the contralateral side, as is the chin point, and elevation of the ipsilateral ear. This midfacial rotation also accounts for the anterior auricular position on the affected side. On the affected side palpebral fissure is rounded and shortened transversely. On the contralateral side, the forehead is bossed, the supraorbital rim is rotated anteroinferiorly, and the palpebral fissure can be slightly narrowed (30). An AP radiograph usually demonstrates the characteristic harlequin eye deformity. Di Rocco and Velardi proposed classifying plagiocephaly into three groups according to the severity of the skull base asymmetry: type I presents a frontal flat and the lesser wing of the sphenoid is displaced upward without skull base asymmetry, type II presents a deviation of the ethmoid and vomer associated with a forward displacement of the petrous part of the temporal bone, and type III is the most serious form with deviation of the basal part of the occipital (15).

Bruneteau and Mulliken believe that physical examination focusing on the supraorbital rims, nasal root, ears, and malar eminences can easily distinguish between synostotic and deformational plagiocephaly (5). Indications for surgery are to improve appearance and to relieve increased intracranial pressure when present.

Since the introduction of craniofacial surgery by Tessier in the late 1960s, the operative technique of craniosynostosis has changed. The first procedure for the treatment of synostotic frontal plagiocephaly was frontoparietal suturectomy (strip craniectomy) $(12,13)$ The next procedure, termed lateral canthal advancement, was described by Hoffman and Mohr $(35,23,14,17,18)$ and later modified by Whitaker et al. and McCarthy et al. $(33,51)$ However, unilateral frontoorbital positioning ignored the compensational deformity in the contralateral forehead. Therefore, Marchac introduced bilateral fronto-orbital advancement; since the report of Marchac and Renier's frontal and bilateral supraorbital reshaping for plagiocephaly, several similar techniques (9, 29) have been described The plethora of reconstructive techniques described by many authors for the treatment of anterior plagiocephaly attests to the fact that no procedure has as yet entirely satisfied the needs of the surgeons to achieve excellent results on a permanent basis (24-26, 38, 39, 42).

At present, the total fronto-orbital reshaping, including the correction of the rotational deformity of the supraorbital area by multiple incomplete osteotomy and rigid fixation, has been performed. The surgical strategy is to make the deformed supraorbital area and forehead symmetric to the contralateral side. Hansen and Mulliken detailed characteristic deformities and stressed the importance of reconstruction of the supraorbital contour on the involved side. Once it is concave, an onlay cranial graft may be needed. In 1994, they described the supraorbital bar as symmetrically positioned with parallelogrammic adjustment on the contralateral side $(22,28,49)$. Early craniofacial correction for frontal plagiocephaly results in a stable, acceptable aesthetic result. The most commonly associated craniofacial characteristics are corrected well to very well if surgery is performed within the first 6 to 15 months of the child's life (45). Symptomatic palpability of the plaque-screw used during the operation is a general problem. This problem is removed by using absorbable plaque-screws. Sufficient rigidity is provided with absorbable plaque-screws until completion of bone healing.

CT scans are used in cephalometric and antropometic measurements. There are so many technical problems for standardization of radiographic data in the patients with marked asymmetry (48). Besides, the patient receives extra radiation from these imagining techniques. As the average age of the patients operated due craniosynostosis is low, intravenous sedation is required during these procedures. These measurements take a lot of time. The most important criterion is self-perception of the patient. But objective self assessment of the patient can be lacking. Thus, assessment disharmony between surgeons and patients is too meaningful (50). Satisfaction of the patients and their relatives are high for both scar and skull form following plagiocephaly surgery. Many scales indicating this satisfaction were constituted. In their serial including 250 patients, Sloan et al., examined the cases regarding residual deformity, irregularity, complication, mortality and need for additional surgery. They evaluated the results with their own scales (47). Also we evaluated our cases by using this scale. Plaque-screw and/or wire were visible subcutaneously in 2 cases, they could be noticed in 3 cases by palpation, and in 1 patient visual or palpable irregularities requiring surgical correction were detected (e.g., removal of plaque-screw). None of these patients admitted reoperation. Follow-ups of the patients are going on.

More patients are required to evaluate the long-term results and the treatment parameters. Surgery outcomes by means of cosmetic improvements in skull form are generally satisfying for the parents and the patients themselves. 


\section{REFERENCES}

1. Alderman BW, Fernbach SK, Greene C, Mangione EJ, Ferguson SW: Diagnostic practice and the estimated prevalence of craniosynostosis in Colorado. Arch Pediatr Adolesc Med 151:159-164, 1997

2. Anonymous: Plagiocephaly and torticollis in young infants. Lancet 2(8510):789-790, 1986

3. Bartlett SP, Whitaker LA, Marchac D: The operative treatment of isolated craniofacial dysostosis (plagiocephaly): A comparison of the unilateral and bilateral techniques. Plast Reconstr Surg 85: 677-683, 1990

4. Blaser SI: Abnormal skull shape. Pediatr Radiol 38 (Suppl 3):488-496, 2008

5. Bruneteau RJ, Mulliken JB: Frontal plagiocephaly: Synostotic, compensational, or deformational. Plast Reconstr Surg 89: 21-33, 1992

6. Captier G, Leboucq N, Bigorre M, Canovas F, Bonnel F, Bonnafé A, Montoya P: Plagiocephaly: Morphometry of skull base asymmetry. Surg Radiol Anat 25: 226-233, 2003

7. Cohen MM Jr: The etiology of craniosynostosis. In Cohen MM Jr(ed): Craniosynostosis: Diagnosis, Evaluation and Management. New York: Raven Press, 1986:65-66

8. Cohen MM, MacLean RE: Sutural biology. In: Cohen and MacLean eds. Craniosynostosis: diagnosis evaluation and management. New York: Oxford University Press, 2000:11-23

9. Cohen SR, Kawamoto HK, Burstein F, Peacock WJ: Advancement-onlay: An improved technique of frontoorbital remodeling in craniosynostosis. Childs Nerv Syst 7:264-271, 1991

10. Cronzy A, Yettou H, Forlodou P, Ricbourg B, Jacquet G, Godard J: Cranial asymmetries: Reflection on plagiocephalies: Premature sutural synostosis or extracranial origin? Neurochirurgie 40: 81-95, 1994

11. Cunningham ML, Heike CL: Evaluation of the infant with an abnormal skull shape. Curr Opin Pediatr 19:645-651, 2007

12. Currarino G: Premature closure of the frontozygomatic suture: Unusual frontoorbital dysplasia mimicking unilateral coronal synostosis. AJNR Am J Neuroradiol 6:643-646, 1985

13. David JD, Poswillo D, Simpson D: The craniosynostosis: Causes, natural history, and management. Berlin Heidelberg New York: Springer, 1982:153

14. Di Rocco C, Velardi F: Innovative thoughts and approaches in the surgical treatment of craniosynostosis. Child's Nerv Syst 12:637-639, 1996

15. Di Rocco C, Velardi F: Nosographic identification and classification of plagiocephaly. Childs Nerv Syst 4: 9-15, 1988

16. Esparza J, Muñoz MJ, Hinojosa J, Romance A, Muñoz A, Méndez MD: Operative treatment of the anterior synostotic plagiocephaly: Analysis of 45 cases. Childs Nerv Syst 14: 448-454, 1998

17. Francel PC, Park TS, Marsch JL, Kaufman BA: Frontal plagiocephaly secondary to synostosis of the frontosphenoidal suture. Case report. J Neurosurg 83:733-736, 1995
18. Genitori L, Zanon N, Denis D, Erdincler P, Achouri M, Lena G, Choux M: The skull base in plagiocephaly. Childs Nerv Syst 10:217-223, 1994

19. Glass IA, Chapman S, Hockley AD: A distinct autosomal dominant craniosynostosis-brachydactyly syndrome. Clin Dysmorphol 3:215-223, 1994

20. Glicksohn J, Kapelusshnik J, Bar-Ziv J, Myslobodsky M: A new look at sleep position via head slant. Funct Neurol 8: 347-350, 1993

21. Gorlin RJ, Cohen MM, Levin LS: Syndromes of the Head and Neck, d 3. New York: Oxford University Press, 1990: chap 14

22. Hansen M, Mulliken JB: Frontal plagiocephaly. Diagnosis and treatment. Clin Plast Surg 21: 543-553, 1994

23. Hoffman HJ: Procedure of lateral canthal advancement for the treatment of coronal synostosis. Childs Nerv Syst 12: 678-682, 1996

24. Jackson IT, Costanzo C, Marsh WR, Adham M: Orbital expansion in plagiocephaly. Br J Plast Surg 41:16-19, 1988

25. Jackson IT, Munro IR, Salyer KE: Atlas of craniomaxillofacial surgery. St Louis: Mosby, 1982: 466-467

26. Jane JA, Park TS, Zide BM, Lambruschi P, Persing JA, Edgerton MT: Alternative techniques in the treatment of unilateral coronal synostosis. J Neurosurg 61:550-556, 1984

27. Kane AA, Mitchell LE, Craven KP, Marsh JL: Observations on a recent increase in plagiocephaly without synostosis. Pediatrics 97:877-885, 1996

28. Kim SW, Shim KW, Plesnila N, Kim YO, Choi JU, Kim DS: Distraction vs remodeling surgery for craniosynostosis. Childs Nerv Syst 23:201-206, 2007

29. Marchac D, Renier D, Jones BM: Experience with the floating forehead. Br J Plast Surg 41:1-15, 1988

30. Marsh JL, Gado MH, Vannier MW, Stevens WG: Osseous anatomy of unilateral coronal synostosis. Cleft Palate J 23: 87-100, 1986

31. Marsh J, Vannier MW: The "third" dimension in craniofacial surgery. Plast Reconstr Surg 71: 759-767, 1983

32. Marucci DD, Jones BM, Dunaway DJ, Hayward RD: Unilateral isolated frontosphenoidal craniosynostosis causing frontal plagiocephaly. J Plast Reconstr Aesthet Surg 62: 255-258, 2009

33. McCarthy JG, Glasberg SB, Cutting CB, Epstein FJ, Grayson BH, Ruff G, Thorne CH, Wisoff J, Zide BM: Twenty-year experience with early surgery for craniosynostosis: I. Isolated craniofacial synostosis-results and unsolved problems. Plast Reconstr Surg 96:272-283, 1995

34. Medina LS: Three-dimensional CT maximum intensity projections of the calvaria: A new approach for diagnosis of the craniosynostosis and fractures. AJNR Am J Neuroradiol 21:1951-1954, 2000

35. Mohr G, Hoffman HJ, Munro IR, Hendrick EB, Humphreys RP: Surgical management of unilateral and bilateral coronal craniosynostosis: 21 years of experience. Neurosurg 2: 83-92, 1978

36. Montoya P: Modern imaging of craniofacial malformations. Ann Chir Plast Esthet 42:365-399, 1997 
37. Muenke M., Gripp KW, McDonald-McGinn DM,. Gaudenz K, Whitaker LA, Bartlett SP, Markowitz RI, Robin NH, Nwokoro $\mathrm{N}$, Mulvihill JJ, Losken HW, Mulliken JB, Guttmacher AE, Wilroy RS, Clarke LA, Hollway G, Adès LC, Haan EA, Mulley JC, Cohen MM, Bellus GA, Francomano CA, Moloney DM, Wall $\mathrm{SA}$, Wilkie AOM, Zackai EH: A unique point mutation in the fibroblast growth factor receptor 3 gene (FGFR3) defines a new craniosynostosis syndrome Am J Hum Genet 60:555-64, 1997

38. Mühlbauer W, Anderl H, Schmidt A, Heeckt P, Zenker J, Schaarschmidt B, Höpner F: Asymmetrical cranioorbital facial stenosis. Ann Plast Surg 26:45-51, 1991

39. Persing JA, Jane JA, Delashaw JB: Treatment of bilateral coronal synostosis in infancy: A holistic approach. J Neurosurg 72:171-175, 1990

40. Plooij JM, Verhamme Y, Berge' SJ, van Lindert EJ, BorstlapEngels VM, Borstlap WA: Unilateral craniosynostosis of the frontosphenoidal suture: $A$ case report and a review of literature. J Craniomaxillofac Surg 37: 162-166, 2009

41. Posnick JC: Anterior Plagiocephaly: Unilateral coronal synostosis and Skull molding. In Craniofacial and maxillofacial surgery in children and young adults. Pennsylvania, WB Saunders Com, 2000:127-161

42. Posnick JC: Unilateral coronal synostosis (anterior plagiocephaly): Current clinical perspectives. Ann Plast Surg 36:430-447, 1996

43. Reardon W, Wilkes D, Rutland P, Pulleyn LJ, Malcolm S, Dean JC, Evans RD, Jones BM, Hayward R, Hall CM, Nevin NC, Baraister M, Winter RM: Craniosynostosis associated with FGFR3 pro250arg mutation results in a range of clinical presentations including unisutural sporadic craniosynostosis. J Med Genet 34:632-636, 1997
44. de Ribaupierre S, Czorny A, Pittet B, Jacques B, Rilliet B: Frontosphenoidal synostosis: $A$ rare cause of unilateral anterior plagiocephaly. Childs Nerv Syst 23:1431-1438, 2007

45. Satoh K, Mitsukawa N, Hayashi R, Hosaka Y: Hybrid of distraction osteogenesis unilateral frontal distraction and supraorbital reshaping in correction of unilateral coronal synostosis. J Craniofac Sur 15: 953-959, 2004

46. Seto ML, Hing AV, Chang J, Hu M, Kapp-Simon KA, Patel PK, Burton BK, Kane AA, Smyth MD, Hopper R, Ellenbogen RG, Stevenson K, Speltz ML, Cunningham ML: Isolated sagittal and coronal craniosynostosis associated with TWIST box mutations. Am J Med Genet A 143:678-686, 2007

47. Sloan GM, Wells KC, Raffel C, McComb JG: Surgical treatment of craniosynostosis: Outcome analysis of 250 consecutive patients. Pediatrics 100(1):E2, 1997

48. Tammaro S, Berggren U, Bergenholtz G: Representation of verbal pain descriptors on a visual analogue scale by dental patients and dental students. Eur J Oral Sci 105: 207-212, 1997

49. Tulasne JF, Tessier P: Analysis and late treatment of plagiocephaly. Unilateral coronal synostosis. Scand J Plast Reconstr Surg 15:257-263, 1981

50. Ware JE: Measuring the patients' view: The optimum outcome measure. BMJ 306:1429-1430, 1993

51. Whitaker LA, Bartlett SP, Schut L, Bruce D: Craniosynostosis: An analysis of the timing, treatment and complications in 164 consecutive patients. Plast Reconstr Surg 80:195-212, 1987 